\title{
Exploring the Content Knowledge of Accounting Teachers in Rural Contexts: A Call for a Decoloniality Approach
}

\author{
Habasisa Vincent Molise \\ Sol Plaatje University, Kimberly, South Africa \\ https://orcid.org/0000-0002-3971-0718
}

\begin{abstract}
The purpose of this paper was to investigate deficiencies in the teaching and learning of financial literacy, which is the accounting part of the subject economic and management sciences in Grade 9 in South Africa. The content knowledge of Grade 9 accounting teachers at rural schools compared to those at urban schools, remains a challenge, as many of the former lack qualifications. Teachers at rural schools are considered to have inadequate content knowledge of accounting, owing to a lack of training and continuous professional development. The sample comprised 89 Grade 9 teachers. The study used secondary data that was collected with a questionnaire on different accounting topics to diagnose the difficulties teachers experience teaching accounting content. The items of the questionnaire were clustered into three constructs: analysis and recording of transactions on the accounting equation, understanding accounting concepts and connections between topics and application of accounting principles, and analysis of transactions in subsidiary journals. The results show that there are deficiencies relating to teachers' content knowledge and competence. This finding suggests that teachers in rural areas should undergo professional development to prepare them to teach learners at rural schools. This development should include establishing professional learning communities for sharing scarce instructional resources between various schools.
\end{abstract}

Keywords: Accounting education; Accounting teachers; Content knowledge; Competence; Decoloniality approach

\section{Introduction}

The curriculum practice of economics and management sciences (EMS) remains a challenge to teachers, mainly due to their lack of content knowledge (Pereira \& Sithole, 2020; Alhassan, Abukari \& Samari, 2018). Teachers have inadequate content knowledge because of teaching subject mismatches, because they lack of qualifications, and did not major in accounting (Ward, He, Wang \& Li, 2018; Modise, 2016). Accounting teachers in rural schools do not possess sound knowledge of the subject content they teach (Ward et al., 2018; Ngwenya, 2014). 
These teachers are not professionally supported to improve their content knowledge and practice, which compromises the quality of teaching in accounting (Mohangi, Krog, Stevens \& Nel, 2016). According to Hlalele (2012), rural schools are regarded as deficient, because teachers are incorrectly placed and they teach subjects they did not specialise in during training. In most cases, teachers are unwilling to work in rural schools because they struggle with transport from their places of residence to these schools (Manda, 2014).

I decided to investigate deficiencies in the content knowledge of accounting teachers at rural schools. Kwarteng (2016) suggests that all teachers ensure they have mastered the content knowledge they teach. I argue that ensuring this mastery is the responsibility of subject advisors/learning facilitators (Diseko \& Modiba, 2018). Subject advisors are Department of Basic Education officials who provide professional development support to in-service teachers in the form of workshops. Therefore, subject advisors have a vested responsibility in identifying the content gaps that teachers may have regarding the teaching of accounting (Gegenfurtner, Lewalter, Lehtinen, Schmidt \& Gruber, 2020), and should support teachers by providing the necessary training/workshops. Mukeredzi (2015) explains that professional development of teachers is considered crucial if teachers are to fulfil the requirements for quality teaching and learning of accounting, especially regarding financial literacy, which is part of accounting, and which is being neglected by teachers in their teaching (Ngwenya \& ArekBawa, 2019).

According to Ngwenya and Arek-Bawa (2020), effective teaching requires teachers to have a deep understanding of the concepts of the subject they teach, in this case, accounting equations, accounting concepts and accounting principles. This view is supported by Modise (2016), who asserts that, "an understanding of accounting concepts and how they are related and organized, enables teachers to draw on the content knowledge of the subject in teaching". However, Ngwenya (2019) asserts that teachers are left to struggle with content knowledge challenges and receive little support. Therefore, I argue that rural school teachers are not prepared for their lessons and do not clearly understand what is expected of them in every lesson.

Akpanobong and Asuquo (2015) assert that effective teaching of accounting requires knowledge integration and skills across topics, and the ability to manipulate accounting equations (Matos, 2020). Findings of a study by Ngwenya and Maistry (2012) indicate that teachers lack the necessary accounting skills to teach the content, which provides learners with few opportunities for logical reasoning in accounting (Hine \& Thai, 2019). Similarly, Manda (2014) confirms that this shortcoming is problematic, as it leaves accounting lessons being taught with a deficit approach, and compromises quality teaching in the subject. Ngwenya's findings corroborate that "teachers who lack subject content knowledge are ill-equipped" to explain and present topics in ways that make sense to learners (2014). I argue, therefore, that when teachers lack subject content knowledge, they tend to promote surface learning, instead of deep learning. 
Da Costa (2020) maintains that teachers with adequate content knowledge are able to make important connections among topics, including using context-based examples when explaining the content to learners (Ngwenya \& Arek-Bawa, 2020; Shepherd, 2013). In turn, Asadullah (2016) found that rural school teachers struggle to show how the content they teach connects to the learners' real-life experiences (Bietenbeck, Piopiunik \& Wiederhold, 2018). I argue that there is a need to reconsider the way teaching and learning of accounting are conceptualised, especially in rural schools, to deal with teachers' content knowledge deficiencies.

\section{Decoloniality as a theoretical lens}

This paper is grounded on decoloniality, which serves as a theoretical lens. Decoloniality was used as an approach to deconstruct and dismantle the narratives and discourses that exist in the curriculum practice of accounting teachers in rural contexts, and the main challenges they face in their classrooms (Dube \& Molise, 2018). Decoloniality is a vehicle for human emancipation, as it considers suppressed voices (Ndlovu-Gatsheni, 2013); in this case, it is meant to rehumanise accounting teachers, who have been subject to systemic oppression by colonisation, which is prevalent in rural classrooms (Vorster \& Quinn, 2017). This view is corroborated by Luckett (2016), who explains that teachers are usually forced to accept and implement the curriculum by district officials, without the opportunity to provide inputs or to share best practices they have acquired from teaching in rural contexts. However, Zipin, Fataar and Brenann (2015) state that subject advisors' knowledge is considered to be the only powerful knowledge (Adam, 2020), because of the powerful status advisors assume in relation to their rural school-based counterparts (Exley, Whatman \& Singh, 2018). Therefore, using a decoloniality approach in this study allowed teachers to speak openly about the challenges they faced in teaching accounting.

The researcher is of the view that some challenges teachers face relate to subject allocation mismatches, lack of suitable qualifications, and ineffective support by the district, which are drawbacks that position teachers to fail to execute the accounting curriculum as intended by the Department of Basic Education (Lockley, 2018). Decoloniality is also about gaining and building curriculum consciousness on these shortcomings, which, independently and progressively, encourages optimum implementation and curriculum delivery in rural contexts, so that a Eurocentric environment, similar to that of the oppressor, is circumvented (Seehawer, 2018).

In this paper, decolonising the accounting curriculum meant using local, relevant examples of accounting and applying knowledge of accounting in the teachers' contexts, or reorienting certain accounting concepts to address content problems, such as analysis and recording of transactions on the accounting equation, understanding accounting concepts, linking topics, applying accounting principles and analysing transactions in subsidiary journals (South Africa, Department of Basic Education, 2011). Le Grange (2016) concludes that decolonised curriculum practice for accounting in rural contexts would require discarding the wrong writings of the oppressor, and interrogating distortions of 
people's life experiences, negative labelling, deficit theorising and genetically or culturally deficient models that pathologise rural accounting teachers; retelling stories of the past and envisioning the future (Ndlovu-Gatsheni, 2013). This idea is supported by Fataar (2012), who calls for reinvigorating production of knowledge that is relevant, effective, and empowering for accounting teachers in rural contexts.

Therefore, to counter the Eurocentrism of accounting teaching in rural schools, we need to decolonise the curriculum and content in accounting classrooms (Hlalele, 2012). I hold the view that doing so will maintain a social order and rules through which an effective culture of accounting teaching can evolve; foster an understanding of rural teachers' consciousness; facilitate a critical emancipatory approach to solving accounting problems teachers experience in accounting lessons; and produce material and capacities for accounting teachers to know how the content should be presented effectively in their classrooms (Pereira \& Sithole, 2019). The knowledge system that was geared to promote colonisation of the accounting curriculum paid little attention to affirming the indigenous knowledge of rural teachers, which resulted in "book knowledge" production (Seehawer, 2018). Salami and Okeke (2017) argue that knowledge production is not about memorising facts, but is, instead, a learning experience that arises from contextualised experiences. I argue in this paper that decolonising accounting teaching should incorporate inclusion, recognition, and affirmation of rural contextual knowledge, which is seldom considered by subject advisors when they provide opportunities for the professional development of accounting teachers, so that teachers can execute curriculum effectively during their lessons.

\section{Unpacking realities in the teaching of accounting in rural contexts}

"Rurality" has always been associated with "lack and characterized by loss" (Alhassan, et al, 2018; Hlalele, 2012). However, rural schools have always survived, regardless of the material conditions of teaching, such as lack of resources, which exist in that context. Thus, accounting teachers need to view these shortcomings as an opportunity to try out new ways of teaching, instead of complaining about the support they receive, to ensure effective curriculum delivery (Pereira \& Sithole, 2020). For instance, accounting teachers need to ensure that the curriculum they teach is relevant to the context in which they teach, by taking advantage of the unique experiences of the learners, to utilise learners' prior knowledge about accounting concepts (Lindsjö, 2018). I argue that, unless the content taught to learners in rural contexts is made relevant to their real-life experiences, then teaching and learning will remain deficient.

According to Qhosola (2015), accounting subject content knowledge includes "knowledge of facts, concepts, procedures, and the relationships among them; knowledge of the ways that subject ideas can be represented (Ward et al., 2018; Manda, 2014), and knowledge of the subject as a discipline" (Ngwenya, 2019; Kwarteng, 2016. Research has shown that the lack of subject content knowledge is likely to influence the way teachers teach content in their lessons (De Lange, Khau \& Athiemoolam, 2014). Lindsjö (2018) emphasises that teachers' subject content knowledge is important for ensuring that relevant content is taught to the learners 
(Ngwenya \& Arek-Bawa, 2019). This means that the mastery of content knowledge is key to ensuring effective teaching and learning in the accounting curriculum.

Quan-Baffour and Arko-Achemfuor (2009) assert that, "accounting teachers are not in touch with market expectations. In addition to teaching accounting topics, teachers are expected to have a broad range of knowledge, skills, and abilities (Ward et al., 2018)". If learners perform well, the honour goes to the school and teachers; however, if they perform badly, the blame ultimately falls on the teacher alone (Da Costa, 2020). I argue that, if teachers receive proper training in, for instance, workshops on the content, they are likely to teach effectively, with confidence, and can motivate learners to like their subjects and work harder and, subsequently, improve accounting results. Mastery of the content can reduce anxiety in accounting teachers and their learners, because both parties become more familiar with the course material and incorporate new methods of teaching and learning accounting (Hine \& Thai, 2019). Omotayo (2014) maintains that it is important for accounting teachers to understand the motives, expectations, and preparedness of learners (Matos, 2020), so that teachers can develop learning environments that promote high-quality learning outcomes. I am of the view that, if teachers are to satisfy the requirements of curriculum reform in accounting, they need to refine their content knowledge.

\section{Research design and methods}

A quantitative research approach that incorporated a content-based questionnaire was used to investigate the content knowledge deficiencies of accounting teachers. The participants, data collection instruments and analysis are described as follows.

\subsection{Participants}

The data were generated through the administration of a questionnaire to Grade 9 EMS teachers from 15 schools in Thabo Mofutsanyane education district in the Free State province. The questionnaire consisted of two sections. Section A comprised 25 accounting questions, which were structured so that different accounting topics were assessed, to diagnose whether teachers experienced difficulties in understanding the content of accounting. Section B investigated the biographical characteristics of teachers. A total of 89 Grade 9 teachers participated: 45 men and 44 women.

\subsection{Instrumentation}

The content-based questionnaire was used to generate data on the content challenges that accounting teachers experience as a result of lack of content knowledge. The questionnaire was used to identify the specific problem areas of accounting content, so as to understand the kind of support teachers need to improve their content knowledge. The questionnaire was structured in a way that that ensured that respondents understood the questions, and how they were supposed to respond to questions. To ensure clarity, questions were arranged from simple to complex questions phrased at different cognitive levels. 
The data were collected by administering the questionnaire at the selected schools, which were sampled because the EMS curriculum was taught at these schools. It was easy to administer the questionnaire at schools, because the centres were easily accessible to teachers in the location and their neighbouring schools. I involved other people to help administer and invigilate the questionnaire at certain schools, and the university involved always had a representative overseeing the specific centres.

The content-based questionnaire was structured such that it addressed three main constructs of Grade 9 accounting themes. From the themes, the following constructs were developed to determine the content knowledge level of accounting teachers: analysis and recording of transactions on the accounting equation; understanding of accounting concepts and connections between topics; application of accounting principles and analysis of transactions in the subsidiary journals. These three constructs served as important elements in assessing the teachers' content knowledge.

The data collected through the questionnaire instrument were captured in Microsoft Excel files which were imported into the Matlab software package for analysis. In this paper, I use a quantitative approach. I calculated the frequency for each answer given per question, and express it as percentages. I use frequency table to visualise the frequencies.

\subsection{Validity and reliability}

The accounting content items included in the questionnaire were selected to assess different cognitive levels. The questionnaire was moderated by the senior subject advisor for accounting in the Free State province. Furthermore, the questionnaire was administered under the supervision of the researcher and research assistants.

\section{Findings}

This section will discuss the analysis and interpretation of data that were gathered through the content-based questionnaire that was organised according to the following themes: analysis and recording of transactions on the accounting equation; understanding of accounting concepts and connections between topics; application of accounting principles and analysis of transactions in the subsidiary journals.

Table 1: Frequencies of applicable content knowledge

\begin{tabular}{|l|l|c|c|}
\hline \multirow{2}{*}{ Themes/Constructs } & $\begin{array}{c}\text { Transactions based on } \\
\text { accounting content }\end{array}$ & $\begin{array}{c}\% \text { correct } \\
\text { responses }\end{array}$ & $\begin{array}{c}\% \\
\text { incorrect } \\
\text { responses }\end{array}$ \\
\hline \multirow{2}{*}{$\begin{array}{l}\text { Theme 1: Analysis and } \\
\text { recording of transactions on } \\
\text { the accounting equation }\end{array}$} & Profit mark-up & $27.5 \%$ & $72.5 \%$ \\
\cline { 2 - 4 } & Bad debts & $27.5 \%$ & $72.5 \%$ \\
\cline { 2 - 4 } & Debtors/creditors & $32.5 \%$ & $67.5 \%$ \\
\hline \multicolumn{2}{|r|}{ Average \% per construct } & $29.2 \%$ & $70.8 \%$ \\
\hline & Assets & $10.9 \%$ & $89.1 \%$ \\
\cline { 2 - 4 } & Income & $12.5 \%$ & $87.5 \%$ \\
\hline
\end{tabular}




\begin{tabular}{|c|c|c|c|}
\hline \multirow{3}{*}{$\begin{array}{l}\text { Theme 2: Understanding } \\
\text { accounting concepts and the } \\
\text { connection between topics }\end{array}$} & Expenses & $17.5 \%$ & $82.5 \%$ \\
\hline & Equity & $27.5 \%$ & $72.5 \%$ \\
\hline & Liabilities & $50 \%$ & $50 \%$ \\
\hline \multicolumn{2}{|c|}{ Average $\%$ per construct } & $23.7 \%$ & $76.3 \%$ \\
\hline \multirow{3}{*}{$\begin{array}{l}\text { Theme 3: Application of } \\
\text { accounting principles and } \\
\text { analysis of transactions in } \\
\text { subsidiary journals }\end{array}$} & Posting to ledger & $17.5 \%$ & $82.5 \%$ \\
\hline & $\begin{array}{l}\text { Drafting of final } \\
\text { accounts }\end{array}$ & $62.5 \%$ & $37.5 \%$ \\
\hline & Subsidiary journals & $77.5 \%$ & $22.5 \%$ \\
\hline \multicolumn{2}{|c|}{ Average $\%$ per construct } & $52.5 \%$ & $47.5 \%$ \\
\hline
\end{tabular}

The frequencies of correct and incorrect responses regarding applicable content knowledge are displayed in Table 1, in decreasing order. Furthermore, Table 1 addresses the three themes, which are expressed as percentages of the total number of 89 respondents, organised as follows: analysis and recording of transactions on the accounting equation; understanding of accounting concepts and connections between topics; and application of accounting principles and analysis of transactions in the subsidiary journals.

The first theme provides data on the analysis and recording of transactions in the accounting equation. Theme 1 is based on transactions relating to the content of profit mark-up, bad debts, and debtors/creditors. On average, $70.8 \%$ of the respondents gave incorrect answers, while $29.2 \%$ gave correct answers under this theme. The first transaction required the respondents to calculate the profit markup, and $72.5 \%$ gave incorrect answers, while $27.5 \%$ calculated the profit mark-up correctly. The second transaction required the respondents to calculate the amount to be written off as bad debts, and $72.5 \%$ gave incorrect answers, while 27.5 calculated the amount to be written off as bad debts correctly. The third transaction required the respondents to record the debtor's amount in the general journal by showing the account to be debited/credited; $67.5 \%$ gave the incorrect answer while $32.5 \%$ recorded the correct journal entry.

The second theme provides data on teachers' understanding of accounting concepts, and their ability to link topics. Theme 2 is based on transactions relating to the content of assets, income, expenses, equity, and liabilities. On average, $76.3 \%$ of the respondents gave incorrect answers, and $23.7 \%$ gave correct answers on all the content in this theme. The first transaction required respondents to define what assets are, and $89.1 \%$ gave incorrect answers, while $10.9 \%$ defined the concept of assets correctly. The second transaction required the respondents to classify whether rental income is an expense or income, and $87.5 \%$ gave incorrect answers and $12.5 \%$ classified the amount received from leasing a property correctly as rent income. The third transaction required respondents to record insurance on the accounting equation, and $82.5 \%$ gave the incorrect answer, while $17.5 \%$ recorded insurance correctly as part of expenses on the accounting equation. The fourth transaction required the respondents to define the concept of equity; $72.5 \%$ gave incorrect answers, while $27.5 \%$ defined equity as an accounting concept correctly. The fifth transaction required the respondents to classify whether a loan is an asset, equity, or liability, and $50 \%$ gave incorrect answers, and 50\% classified a loan correctly as a liability. 
The third theme provides data on the application of accounting principles and analysis of transactions in the subsidiary journals. Theme 3 is based on transactions relating to the content of the posting to the general ledger, drawing of final accounts, and subsidiary journals (cash receipt and cash payment journal). On average, $47.5 \%$ of the respondents gave incorrect answers, with $52.5 \%$ giving correct answers on this theme. The first transaction required respondents to post the transaction for the purchase of new machinery to the general ledger, and $82.5 \%$ of the respondents gave incorrect answers, while 17.5 posted the equipment account correctly in the general ledger. The second transaction required respondents to balance off the debtors' control account; $37.5 \%$ gave incorrect answers and $62.5 \%$ correctly balanced off the debtors' control account, with clear identification of balance carried down and balance brought down. The third transaction required respondents to analyse and record a transaction relating to rent received from a tenant in the cash receipt journal; $22.5 \%$ gave incorrect answers and $77.5 \%$ recorded the rent income amount correctly in the cash receipt journal, by transferring the rent amount to the sundry accounts column.

\subsection{Discussion of findings}

This paper investigated deficiencies in the teaching and learning of financial literacy, which is the accounting part of EMS in Grade 9. The findings from the thematic analysis presented in Table 1 confirm that the respondents had inadequate accounting content knowledge. The implication of this finding is explained by Omotayo (2014), namely, that teachers' content knowledge and learners' academic performance are positively related (Matos, 2020; Ngwenya \& Arek-Bawa, 2019). The teachers' content knowledge, in the first instance, influences teachers' performance, which, in turn, enhances learners' achievement (Diseko \& Modiba, 2018). I concur that there is a logical link between these two variables.

Akpanobong and Asuquo (2015) report that teachers' content knowledge is a good predictor of students' achievement in school subjects (Ngwenya, 2019). This finding is in agreement with that of Qhosola (2015), who found that teachers' mastery of their content knowledge is consistent with learners' achievement in accounting (Pereira \& Sithole, 2020). Other factors may also influence teachers' lack of content knowledge - these factors are beyond the scope of this study. The length of service of teachers does not guarantee mastery of content knowledge and learner achievement. Instead, continuous training that teachers receive helps them to apply and display the proficiency acquired from the training/workshops and, thus, leads to quality teaching and learning in their classes (Ngwenya \& Arek-Bawa, 2020). Certain motivational factors, such as financial (salary and other emoluments) and non-financial matters (contentment, passion for teaching, or an interest in the profession) may encourage teachers to be more productive, which may lead to an improvement in academic performance of learners (Ward et al., 2018).

While Shepherd (2013) focused on the qualifications of teachers, the findings of this paper are unique, because they reveal the content knowledge challenges experienced by accounting teachers (Bietenbeck et al., 2020) and how teachers 
apply their understanding of accounting content on topics, such as analysis and recording of transactions on the accounting equation; understanding accounting concepts and connections between topics; and application of accounting principles and analysis of transactions in subsidiary journals.

\subsection{Ways of improving teacher competence in rural school}

Several studies have revealed that the poor performance of Grade 9 rural school accounting learners compared to those at urban schools, is caused by unqualified teachers. After all, "they have inadequate content knowledge of Accounting (Ngwenya, 2014) probably, because they were not properly trained and equipped to teach it competently". Newly qualified teachers do not receive the necessary support and, thus, they lack career development opportunities (Gegenfurtner et al., 2020), especially those at rural schools, which compromises effective teaching to a greater extent in rural than in urban schools. There is a need for professional development workshops meant specifically for rural school teachers, to address their context-based challenges (Diseko \& Modiba, 2018). These workshops should include establishing professional learning communities for rural school teachers, to enable them to share instructional resources and best teaching practices (Lindsjö, 2018). In addition to advanced training, "rural teachers should also have access to distance learning, seminars, and workshops" (Diseko \& Modiba, 2018).

Implementing these measures will provide rural teachers with opportunities to develop an interest in teaching under different conditions and in various cultures. Thus, the "emphasis on background and adequate early exposure for prospective teachers to the rural environments in which they will teach is crucial for teaching in rural schools" (Mukeredzi, 2015). I strongly recommend that rural school teachers facilitate learning in a learner-centred way, in order to accommodate the diverse needs of learners. To do this effectively, teachers should use learnercentred strategies and methods that fit the instructional challenges in the rural context best (Modise, 2016; Qhosola, 2015).

\section{Conclusion}

This paper investigated deficiencies in the teaching and learning of financial literacy, which is the accounting part of EMS in Grade 9. In this paper, data were organised and the findings were discusses per the constructs that were identified. It is evident from the discussion that these constructs are intricately interwoven and, therefore, it is imperative to integrate the different knowledge areas, especially when developing possible solutions for the problems experienced by teachers. This integration can be achieved by establishing the prevalence and impact of the different causes of each problem that was identified. The implication is that diagnosing accounting teachers' problems needs to be done accurately, and identification must be approached thoughtfully. A detailed analysis of the findings should assist in developing teacher development material that is responsive and relevant to addressing the challenges of teacher competence. The study recommends that teachers from rural and urban schools work together by establishing professional learning communities. By enabling rural and urban teachers to work together by setting up a support group, the isolation that teachers often experience can be ended. Teachers working together can find solutions to 
the common problems they face by sharing resources and insight. Using social networking sites for teacher support and learner support could provide continuous professional development (workshops) for accounting teachers.

A limitation of this study is that the data was generated through the use of a content-based questionnaire alone. If interviews could have been conducted, much richer data could have been collected by eliciting respondents' own views on what informs their content knowledge deficiencies in accounting.

\section{References}

Adam, T. (2020). Between social justice and decolonisation: Exploring South African MOOC designers' conceptualisations and approaches to addressing injustices. Journal of Interactive Media in Education, 1(7), 1-11. https:// doi.org/10.5334/jime.557

Alhassan, S. N., Abukari, M. A., \& Samari, J. A. (2018). Exploring the pedagogical content knowledge of experienced senior high schools' science teachers on "states of matter and its changes". East African Journal of Educational Research and Policy, 15, 105-122.

Akpanobong, U. E., \& Asuquo, E. E. (2015). Teacher quality and students' achievement in financial accounting in senior secondary schools in Akwa Ibom State, Nigeria. International Journal of Education and Research, 3(9), 177-188.

Asadullah, S. (2016). Effects of teacher training on secondary teachers' mathematical content knowledge in Dhaka, Bangladesh. International Journal of Innovation and Economic Development, 2(5), 40-55. https://doi.org/10.18775/ijied.1849-75517020.2015.25.2005

Bietenbeck, J., Piopiunik, M., \& Wiederhold, S. (2018). Africa's skill tragedy: Does teachers' lack of knowledge lead to low student performance? Journal of Human Resources, 53(3), 553-578. https:// doi.org/10.3368/jhr.53.3.0616-8002R1

Da Costa, D. A. (2020). Knowledge to teach and knowledge for teaching in teacher education research. Pedagogical Research, 5(3), em0059. https://doi.org/10.29333/pr/7936

De Lange, N., Khau, N., \& Athiemoolam, L. (2014). Teaching practice at a rural school? And why should we go there? South African Journal of Higher Education, 28(3), 748766.

Diseko, R., \& Modiba, W. (2018, June 25). Authentic online assessment in assessing basic accounting content knowledge of Grade 10 learners. In T. Bastiaens, J. Van Braak, M. Brown, L. Cantoni, M. Castro, R. Christensen ... O. Zawacki-Richter (Eds.), EdMedia World Conference on Educational Media and Technology. Proceedings. Association or the Advancement of Computing in Education. Retrieved from https://www.learntechlib.org/primary/p/184556

Dube, B., \& Molise, H. V. (2018). The church and its contributions to the struggle to liberate the Free State province. Journal for Contemporary History, 43(1), 160-177. https://doi.org/10.18820/24150509/JCH43.v1.8

Exley, B., Whatman, S., \& Singh, P. (2018). Postcolonial, decolonial research dilemmas: Fieldwork in Australian indigenous contexts. Qualitative Research, 18(5), 526-537. https://doi.org/10.1177/1468794118778611.

Fataar, A. (2012). Pedagogical justice and student engagement in South African schooling: Working with the cultural capital of disadvantaged students. Perspectives in Education, 30(4), 52-75. Retrieved from https://journals.ufs.ac.za/index.php/pie/article/view/1782. 
Gegenfurtner, A., Lewalter, D., Lehtinen, E., Schmidt, M., \& Gruber, H. (2020). Teacher expertise and professional vision: Examining knowledge-based reasoning of preservice teachers, in-service teachers, and school principals. Frontiers in Education, 5, 59. https://doi.org/10.3389/feduc.2020.00059

Hine, G., \& Thai, T. (2019). Pre-service mathematics teachers' self-perceptions of readiness to teach secondary school mathematics. Mathematics Teacher Education and Development, 21(2), 64-86.

Hlalele, D. (2012). Exploring rural high school learners' experience of mathematics anxiety in academic contexts. South African Journal of Education, 32, 267-278.

Le Grange, L. (2016). Decolonization of the university curriculum. South African Journal of Higher Education, 30(2), 1-12. http:// dx.doi.org/10.20853/30-2-709

Lindsjö, K. (2018). Contextualizing the quality of primary education in urban and rural contexts: The case of Iringa Region, Tanzania. Norsk Geografisk Tidsskrift/Norwegian $\begin{array}{llll}\text { Journal of } & \text { Geography, 234-247. }\end{array}$ https://doi.org/10.1080/00291951.2018.1492962

Lockley, P. (2018). Open initiatives for decolonising the curriculum. In, G. K. Bhambra, K. Nişancioğlu, \& D. Gebrial (Eds.), Decolonising the university (pp. 145-173). London: Pluto Press.

Luckett, K. (2016). Curriculum contestation in a post-colonial context: a view from the South. Teaching in Higher Education, 21(4), 415-428. https:// doi.org/10.1080/13562517.2016.1155547

Manda, D. C. (2014). An investigation on the shortage of accounting teachers and its effect on high schools pass rates in Vhembe District Limpopo province, South Africa. Journal of Social Sciences, 41(3), 433-440. https:// doi.org/10.1080/09718923.2014.11893378

Matos, J. M. (2020). Construing professional knowledge of secondary school teachers of mathematics: A historical perspective. Pedagogical Research, 5(3), em0058. https://doi.org/10.29333/pr/7898

Modise, A. M. (2016). Pedagogical content knowledge challenges of accounting teachers. International Journal of Educational Sciences, 13(3), 291-297. https://doi.org/10.1080/09751122.2016.11890464

Mohangi, K., Krog, S., Stephens, O., \& Nel, N. (2016). Contextual challenges in early literacy training and learning in Grade $\mathrm{R}$ rural schools in South Africa. Per Linguam, 32(1), 71-87. http://dx.doi.org/10.5785/32-1-646

Mukeredzi, T.B. (2015). Creating space for pre-service teacher professional development during practicum: a teacher educators' self-study. Australian Journal of Teacher Education, 40(2), 126-145.

Ndlovu-Gatsheni, S. J. (2013). The entrapment of Africa within the global colonial matrices of power: Eurocentrism, coloniality, and de-imperialization in the twenty-first century. Journal of Developing Societies, 29(4), 331-353. https:// doi.org/10.1177/0169796X13503195

Ngwenya, J. C. (2014). Accounting teachers' understandings and practices of teaching and assessment in the context of curriculum change. Alternation, 21(1), 171-189.

Ngwenya, J. C. (2019). Accounting teachers' experiences of providing feedback in a selected rural school in South Africa: possibilities for communal feedback. South $\begin{array}{llll}\text { African Journal of Education, 39(S2), S1-S12. } & \end{array}$ https:// doi.org/10.15700/saje.v39ns2a1502

Ngwenya, J., \& Arek-Bawa, O. (2019). Exploring the quality of Grade 12 accounting education textbooks. The Journal for Transdisciplinary Research in Southern Africa, 15(1), a662. https://doi.org/10.4102/td.v15i1.662 
Ngwenya, J. C., \& Arek-Bawa, O. (2020). Assessment in textbooks: exploring cognitive demand in first-year accounting textbooks. South African Journal of High Education, 34(1), 176-196. http://dx.doi.org/10.20853/34-1-3370

Ngwenya, J. C., Maistry S. M. (2012). Teaching and assessment in Accounting: An exploration of teachers' experiences in a rural KwaZulu-Natal school. Journal of Social Sciences, 33(1), 21-30. https:// doi.org/10.1080/09718923.2012.11893083

Omotayo, B. K. (2014). Teachers' characteristics and students' performance level in senior secondary school financial accounting. Journal of Empirical Studies, 1(2), 48-53.

Pereira, L., \& Sithole, B. M. (2019). Towards constructivist learning and teaching in accounting education. Journal of Emerging Trends in Educational Research and Policy Studies, 10(1), 1-9.

Pereira, L., \& Sithole, B. M. (2020). Learner-centered pedagogy in accounting: Understanding its meaning from a Bernsteinian perspective. African Educational Research Journal, 8(1), 20-30. https://doi.org/10.30918/AERJ.81.20.002

Qhosola, M. R. (2015). Accounting teacher preparation: A critical accounting perspective. Council for the Development of Social Science Research in Africa, 13(1\&2), 213-228.

Quan-Baffour, K. P., \& Arko-Achemfuor, A. (2009). Bridging the content knowledge gap of teachers: An agenda to improve business studies teaching in South African countryside schools. Problems of Education in the 21st Century, 12, 108-116. Retrieved from http://hdl.handle.net/10500/14405

Salami, I. A., \& Okeke, C. I. O. (2017). Transformation and decolonization of mathematics education for sustainable development: A case study of its learning trend in Nigeria. Perspectives in Education, 35(2), 45-59. https://doi.org/10.18820/2519593X/pie. v35i2.4

Kwarteng, J. T. (2016). Concerns of accounting teachers in implementing Ghana's 2007 education reform: Revisited. International Online Journal of Education and Teaching (IOJET), 3(3). 212-216. $\quad$ Retrieved from http://iojet.org/index.php/IOJET/article/view/137/136

Seehawer, M. (2018). Decolonising research in a sub-Saharan African context: Exploring ubuntu as a foundation for research methodology, ethics and agenda. International Journal of Social Research Methodology, 21(4), 453-466. https:// doi.org/10.1080/13645579.2018.1432404

South Africa, Department of Basic Education. (2011). Curriculum and assessment policy statement: Accounting. Further Education and Training Phase, Grades 10-12. Pretoria: Government Printer.

Shepherd, D. L. (2013). The impact of teacher subject knowledge on learner performance in South Africa: a within-pupil across-subject approach. International Workshop on Applied Economics of Education (pp. 1-32). Cantanzaro, Italy.

Vorster, J. A., \& Quinn, L. 2017. The 'decolonial turn': What does it mean for academic staff development? Education as Change, 21(1), 31-49. https://doi.org/10.17159/1947-9417/2017/853

Ward, P., He, Y., Wang, X., \& Li, W. (2018). Chinese secondary physical education teachers' depth of specialized content knowledge in soccer. Journal of Teaching in Physical Education, 37 (1), 101-112. https:// doi.org/10.1123/jtpe.2017-0092.

Zipin, L., Fataar, A., \& Brennan, M. (2015). Can social realism do social justice? Debating the warrants for curriculum knowledge selection. Education as Change, 19(2), 9-36. https:// doi.org/10.1080/16823206.2015.1085610 